\title{
WORKSHOPS IN ARCHITECTURAL TECHNOLOGY: A NEW COLLABORATIVE APPROACH
}

\author{
M.D. Andújar-Montoya, E. García González, M.A. López Peral \\ University of Alicante (SPAIN)
}

\begin{abstract}
Traditional university teaching based solely on the lecture is increasingly being recognized as ineffective. The classic lecture, where all the attention is focused on the professor, is widely considered to be an insufficient method of learning. Student needs require a change in their learning role-from passive to active- in the acquisition of knowledge. University teaching should facilitate selfdirected learning, where the teacher sets standards and the student becomes a problem solver. This new paradigm has been put into practice through the running of workshops in several modules of the Architectural Technology Degree at the University of Alicante. Thus, the student becomes active in the learning process by solving new problems, by interacting with peers and, at times, in the case of Erasmus students, is able to contribute a view from a different cultural perspective. These workshops highlight the need to have a global vision as they have been enriched by workshop visits from specialist teaching staff of other universities in Spain and abroad. This paper demonstrates the advantages of active learning, such as, developing teamwork skills whereby students become more resourceful, able to cooperate, exchange knowledge, and when required, communicate in different languages. The final goal is to train building engineers who can solve problems effectively as part of a team.
\end{abstract}

Keywords: workshop, teaching staff, Knowledge, teamwork, motivation.

\section{INTRODUCTION: THE CONTEXT OF THE SUBJECT FUNDAMENTALS OF CONSTRUCTION}

The subject Construction Basics in Architectural Technology Degree is a matter of first course of 6 credits with obligatory character, which is taught in the second quarter. It is the continuation of the subject History of the Construction previously imparted in the first quarter, where basic knowledge acquired in the first semester is settled and extended (Fig. 1).

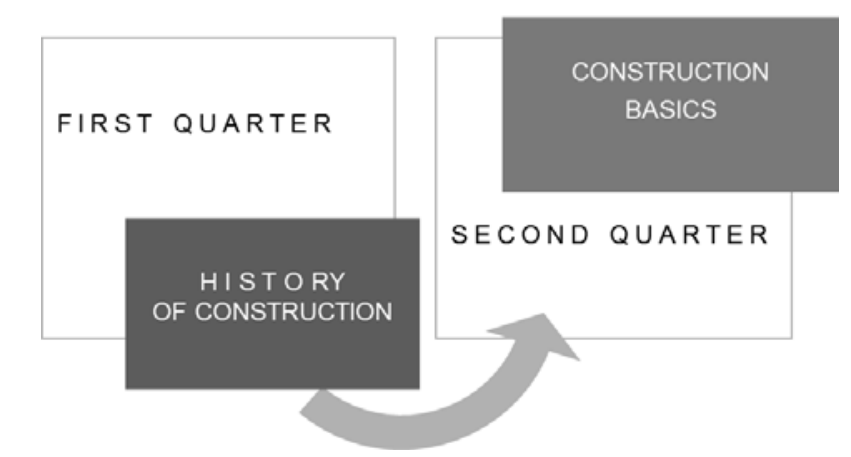

Figure 1. Concatenation of contents between first course subjects.

From the knowledge acquired in the first quarter, new contents are developed based on the identification of basic building elements, allowing students to acquire a global and comparative view of the different constructive solutions of a building. This is its morphology, its function and its behaviour. Likewise, students learn the diversity of materials and its suitability according to each construction typology. In addition students are introduced both in the technical language of the discipline and in the graphic expression of the elements and constructive techniques of the field.

Therefore, the relevance of the subject lies in its importance as a "subject initiation", which serves to students as a basis for acquiring adequate knowledge to continue with the studies of Construction in higher courses, directly as a continuation of contents. 


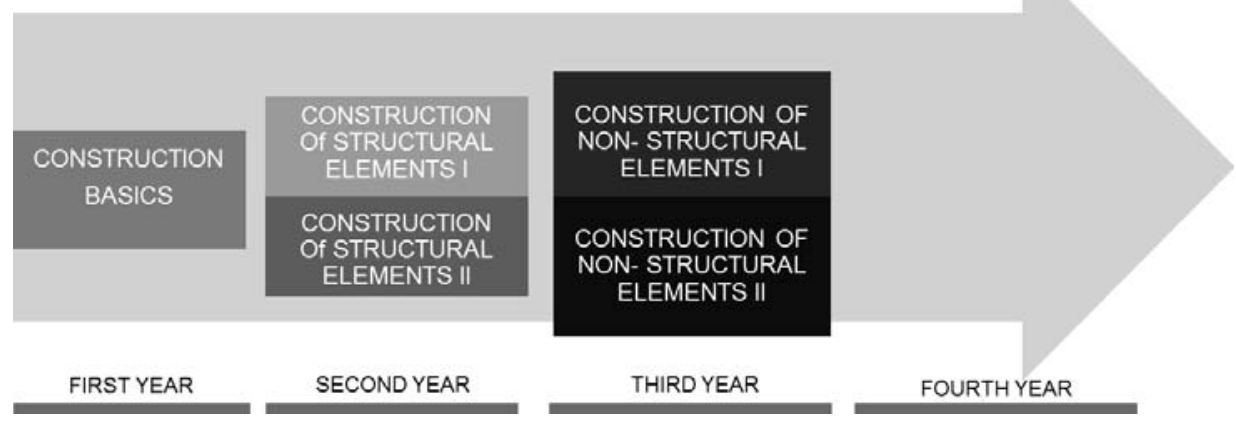

Figure 2. Direct continuity of contents in the rest of the subjects of the degree.

Similarly, as Construction Basis is a core subject, it has a special relevance for its continuity in other subjects of the degree indirectly. This initial subject will allow students to adjust their level of knowledge to the subsequent initial needs, required on the different subjects included in the later courses (Table 1).

Table 1. Indirect continuity with contents in later courses.

\begin{tabular}{|c|c|}
\hline CONSTRUCTION OF STRUCTURAL ELEMENTS I & \\
\hline CONSTRUCTION MATERIALS I & \\
\hline CONSTRUCTION OF STRUCTURAL ELEMENTS II & SECOND YEAR \\
\hline STRUCTURES I & \\
\hline BUILDING FACILITIES I & \\
\hline $\begin{array}{l}\text { CONSTRUCTION MATERIALS II } \\
\text { STRUCTURES II } \\
\text { BUILDING FACILITIES II } \\
\text { WORK EQUIPMENT AND AUXILIARY TOOLS } \\
\text { CONSTRUCTION OF NON-STRUCTURAL ELEMENTS I } \\
\text { ECONOMIC MANAGEMENT; MEASUREMENTS, BUDGETS AND } \\
\text { PROPERTY VALUATIONS } \\
\text { MANAGEMENT AND CONTROL OF QUALITY OF MATERIALS AND } \\
\text { WASTE } \\
\text { HEALTH AND SAFETY IN CONSTRUCTION } \\
\text { CONSTRUCTION OF NON-STRUCTURAL ELEMENTS II }\end{array}$ & THIRD YEAR \\
\hline $\begin{array}{l}\text { URBAN PLANNING } 1 \\
\text { BUILDING PROJECTS } \\
\text { CONSTRUCTION STAKE OUT SURVEYS } \\
\text { PLANNING AND MANAGEMENT OF CONSTRUCTION WORKS } \\
\text { FINAL DEGREE PROJECT }\end{array}$ & FOURTH YEAR \\
\hline $\begin{array}{l}\text { ITINERARY 1. INTERVENTION IN THE BUILT HERITAGE } \\
\text { ITINERARY 2. REAL STATE MANAGEMENT } \\
\text { ITINERARY 3. ENERGY EFFICIENCY } \\
\text { ITINERARY 4. WORK EXPERIENCE }\end{array}$ & $\begin{array}{l}\text { OPTIONAL } \\
\text { ITINERARY }\end{array}$ \\
\hline
\end{tabular}

During the academic year 2015-16, there were offered two groups in Spanish language, one group in Valenciano and one group in English. The present work has focused on the latter English group. The main reason why we have focused on this last group is justified in the following section 1.1 Problem / question: The context of Architectural Technology graduates.

\subsection{The context of Architectural Technology graduates.}

As previously specified, the subject Construction Basis is included in Architectural Technology Degree. Currently the career of the Architectural Technologist is recovering from the economic crisis that has been affecting the sector since 2006 (Fig. 3). This situation has forced a high percentage of 
professionals to seek work abroad. Through surveys sent to Graduates working abroad there were identified the following three main barriers they faced:

- Different language and low level of English;

- Different construction systems;

- Difficulties and social barriers to work in multidisciplinary teams in a collaborative way.

Mainly, these barriers have their origin in the housing bubble with zero unemployment rates, where the knowledge of languages or the search for working abroad was optional rather than necessary.

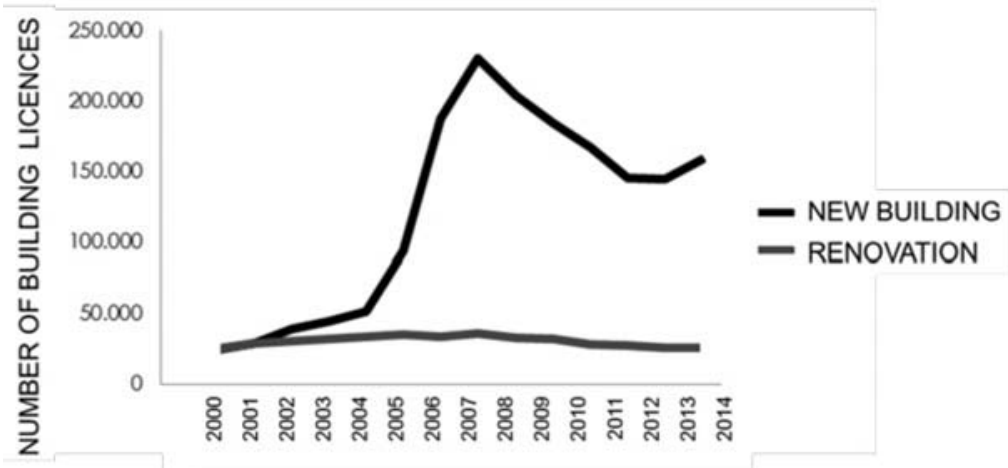

Figure 3. Evolution / Situation of the construction sector reflected through the number of building licenses Source: Own elaboration based on data from the Ministry of Public Works. Http://www.fomento.gob.es/

This recession in the construction industry has not only affected professionals and graduates in a direct way, but also affects the Architectural Technology Degree and its students indirectly. This fact is verified comparing the number of students enrolled in the period of greatest growth of building sector to the current drastic reduction in the number of students enrolled (Fig. 4).

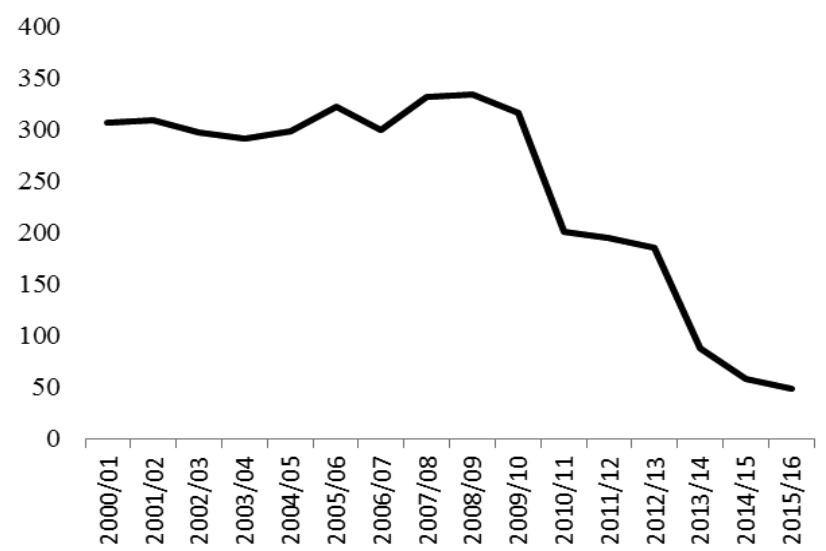

Figure 4. Evolution of student's enrolments from the year 2000 to year 2016 Source: Own elaboration based on data from Alicante University Virtual Campus.

It also affects students indirectly in terms of lack of motivation, due to the uncertainty and unemployment rate in the sector. Likewise, the fear to migrate professionally to another country is a constant, in a degree where the number of Erasmus + scholarships applied by our students is quite low. Again, according to surveys sent to Graduates and last year students, this fear is extended to the international professional outlet that is visualized as a consequence instead of as an opportunity, facing with panic and misfortune. All this magnifies even more a latent problem among our students that is the insecurity and lack of motivation due to the complex technical character of the degree, which often dilates too much over time.

As a consequence, this leads us to rethink if the traditional model of teaching is appropriate in the current environment of Architectural technology. 


\subsection{Problems in the traditional model of higher education teaching}

The traditional model of higher education that involves the development of master classes in front of a passive public is recognized as increasingly inefficient [1]. At the same time, motivation in learning is a key element in the framework of the reform that European universities are implementing, aimed to create the European Higher Education Area (hereinafter EHEA) [2]. According to this reform the current educational needs are based on the development of skills and self-learning abilities. Therefore, the evolution of educational models has made students the main protagonists and true responsible for their learning [2]. Thus students acquire an active and participative role in the process of their own formation [3].

In relation to the aforementioned, the motivation acquires a fundamental importance since if a student is not motivated to learn hard will embark in a trajectory of effort and personal work focused on the development of competences [2]. The relationship between motivation and self-learning is quite reiterative throughout the studied literature, where several authors relate directly the demotivation with the master class [4]. This is a cause of concern due to motivation has a high degree of impact on students' performance.

Given this situation, it is necessary to stimulate the development of a personal attitude for allowing the permanent overcoming of difficulties. It will offer students a greater competitiveness, improving their professional insertion possibilities [3]. This fact is especially relevant due to the specific problem faced by students of the Degree of Architectural technology, as specified in section 1.1. The context of Architectural Technology graduates.

\subsection{Gamification as a motivation strategy}

Given the previous context, it is proposed the use of Gamification strategies, i.e. dynamic strategies which are already proliferating in other fields, such as technology, communication, psychology, education, or health, among others. The main purpose of these strategies is to influence and motivate groups of people with inefficiency problems [1]. This motivation is achieved through the use of game mechanics in non-play environments in order to enhance characteristics such as motivation, concentration, effort, loyalty and other positive values common to all games.

Therefore, it is proposed a learning model based on the motivation of the students, seeking their involvement in the subject Construction Basics.

Through the use of this dynamic methodology -applied to subjects related to the construction sector which are characterized by an eminently practical context- discussions and collaborations will be encouraged. This discussions and collaborations will arise from the resolution of situations, thanks to the diversity of scenarios and situations provided by gamification [5-8].

\section{GAMING STRATEGIES IN THE SUBJECT CONSTRUCTION BASICS}

\subsection{Objectives}

In order to eliminate aspects such as lack of motivation, insecurity and fear generally present in the traditional model of master class in high education, the main objective of this work is the implementation of gamification techniques in the subject Construction Basics in Architectural Technology Degree. To achieve this, the following specific objectives are proposed:

- Involve the students in the sessions seeking their participation actively, making them aware of their achievements and weaknesses to overcome certain thematic blocks.

- Energize the sessions, leaving behind the hieratic figure of the lecture.

- Encourage cooperation and collaboration as a unique way of solving problems. As well as learning to work in collaborative structures based on Integrated Project Delivery (hereinafter IPD) systems.

- Strengthen the personal safety of each student, achieving individual assertiveness.

- Learn other constructive solutions used at an international level, providing a global and international vision of construction, so that students can visualize the experience of working abroad as a positive experience instead of a consequence of the economic conjuncture. 
- Learn the figures and agents involved in the construction process at an international level.

\subsection{Research process based on dynamic learning methods}

The present work is focused on the subject Construction Basics in Architectural Technology Degree, specifically, in the group taught in English, where fun and dynamic work methodology is required to foster cooperation and involvement. At the same time the additional problem of the language requires a method able to strengthen the student's personal security against fear of making grammatical mistakes.

In the academic year 2015-2016 -within this framework of needs and problems detected- a change of perspective was proposed through the development of an international workshop in order to break with the monotony of the traditional master class, as well as changing the physical space where classes are normally taught. Furthermore, I was possible the exchange of knowledge due to the visit of a teaching staff and the collaboration of the Erasmus students (Fig. 5).

As it is shown in Fig. 5, the workshop was developed in two main parts. The first one included short master lessons of thirty minutes of duration with different lecturers of different countries, the short duration sessions avoided students to lose interest in the session, especially considering that it was in a foreign language.

The second part involved students working collaborative in groups, where Spanish students worked together with Erasmus students all that under the guidelines of lecturers of different countries. Another different aspect was the special context, in a special work room of the general library building at the University of Alicante, close to the architecture and construction magazines. The fact of being in a different space, different from usual, produced concentration and excitement among students.

All that features distanced the two weeks sessions far away from the traditional lecture model commonly used.

\section{WORKSHOP DEVELOPMENT:}

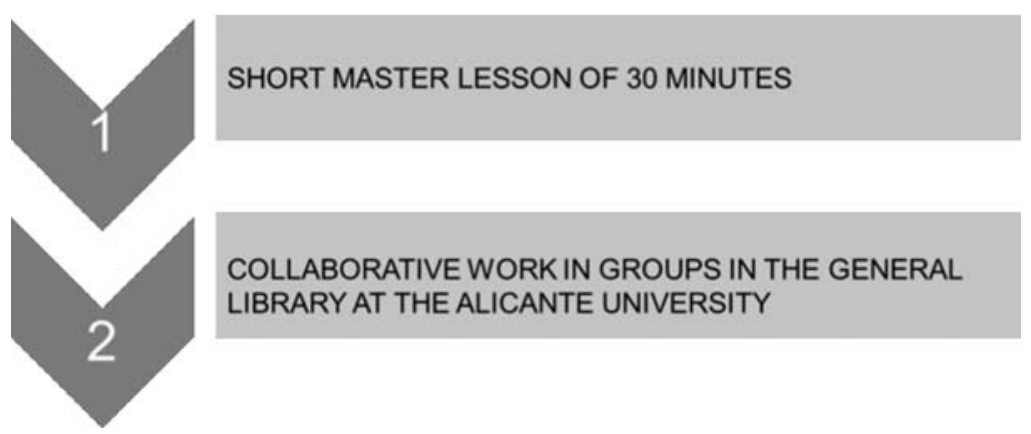

Figure 5. Workshop as a dynamic methodology for gamification.

The workshop was entitled "Building in Spain and Building in Denmark", as Denmark was the nationality of most of the participating Erasmus students and the Visiting Professor. It was held from $11^{\text {th }}$ to $21^{\text {st }}$, of April 2016 (Fig. 6). During the first week, the short master lessons and the collaborative work at the work room of the library building was focused on "Building in Spain". This means that sessions where centred on typologies and construction systems used in Spain for façades and roofs. This exchange of knowledge and collaborative work was satisfactory not only for Spanish and Erasmus students but also for the participating professors.

Similarly during the second week, the workshop was developed around the concept "Building in Denmark"; where Spanish students learned typologies and construction systems used in Denmark for façades and roofs, with the help of the guest Professor, the Danish Erasmus students and by themselves through google searches and the architectural and construction magazines next to the work room at the library building. Again the novelty and the exchange of knowledge was motivating for all the participants. 


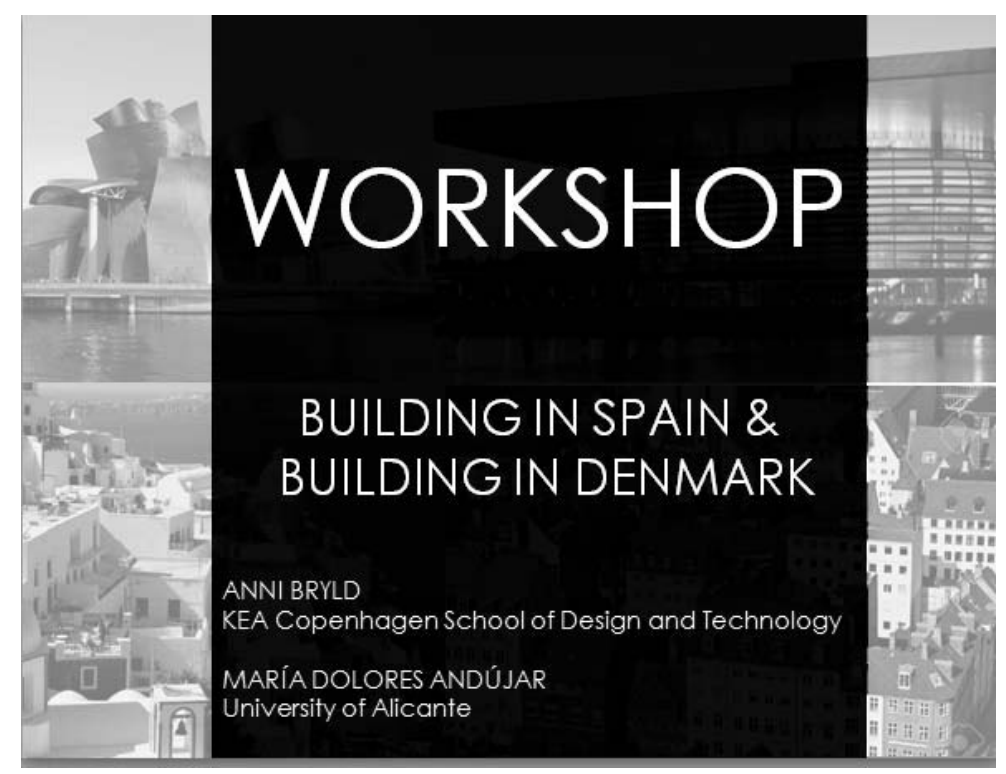

Figure 6. Workshop "Building in Spain and building in Denmark."

This difference of the materials that are integrated in the constructive solutions, and especially the differences of thickness in the layers of those solutions, allowed an interesting discussion in the phase 2 of the workshop, fostering the interaction between the local students and Erasmus students and between the students-teachers.

This fact promoted a broader and global vision of construction, beyond the traditional solutions of each country. In addition it allowed understanding the origin of the constructive traditions of each country, for example, the tendency of using brick in Spain and wood in Denmark; or the onsite construction elements in Spain against the offsite elements in Denmark.

At the same time during the two weeks of the workshop, activities in the library were carried out in phase 2. These activities were related to the search for constructive details in architectural and construction magazines such as Croquis, Arquitectura Viva or Details, among others (Fig. 7).

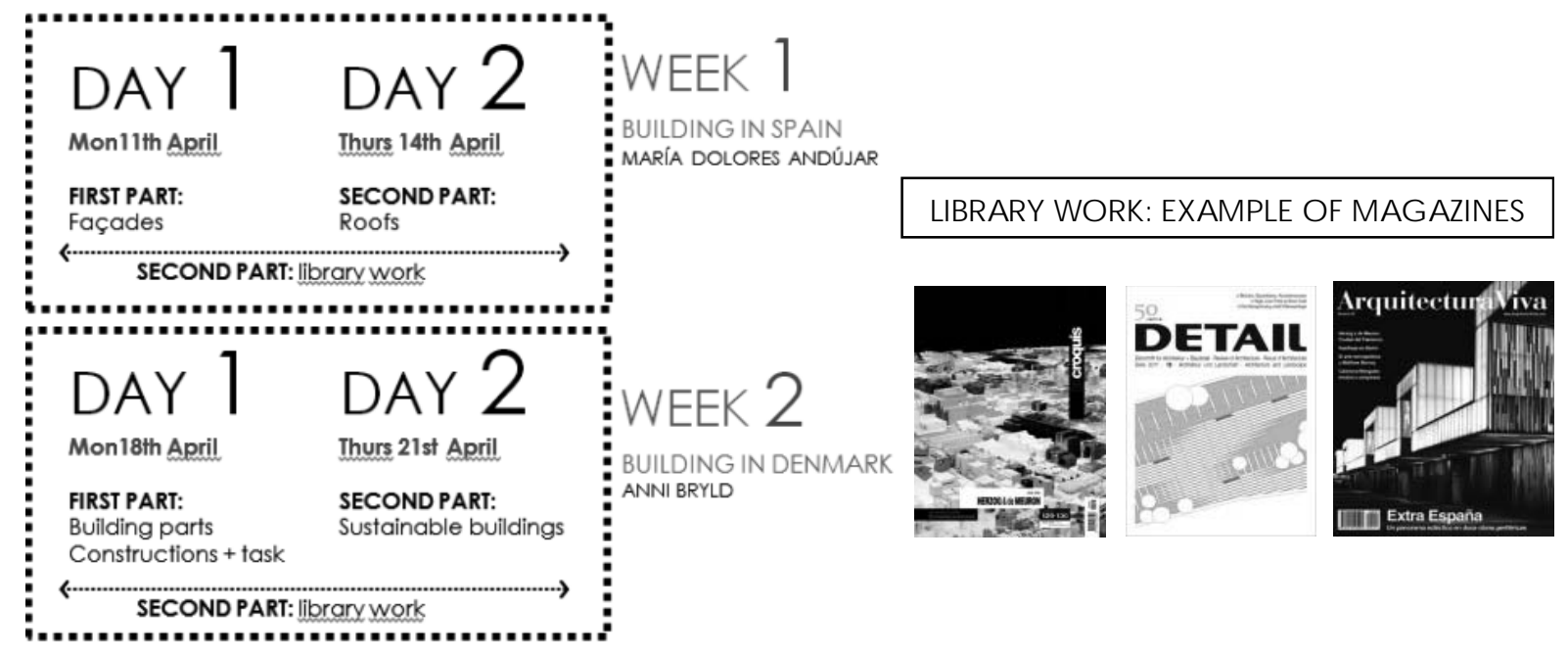

Figure 7. Workshop contents.

The students participating in the workshop were divided into groups of two students to encourage collaborative work, and trying to encourage the grouping of students of different nationalities. Once the members were formed, each group chose a different constructive typology to develop the proposed work. For example, brick facades, monolayer facades, ventilated photovoltaic facades, green roofs, roof with plots, etc... 
After that, the groups of students carried out a bibliographical search, in the architectural and construction magazines of the General Library of the University of Alicante. This research was made in the work places close to the magazines' shelves. There, students were able to deepen and develop different constructive details of the facades and roofs typologies chosen previously. These visualized sections are reproduced by freehand to obtain a sketch of the constructive details of the typologies of facades and covered roofs

Then, these constructive sections previously consulted in the magazines were reproduced by freehand to get a sketch of the constructive details of the chosen typologies.
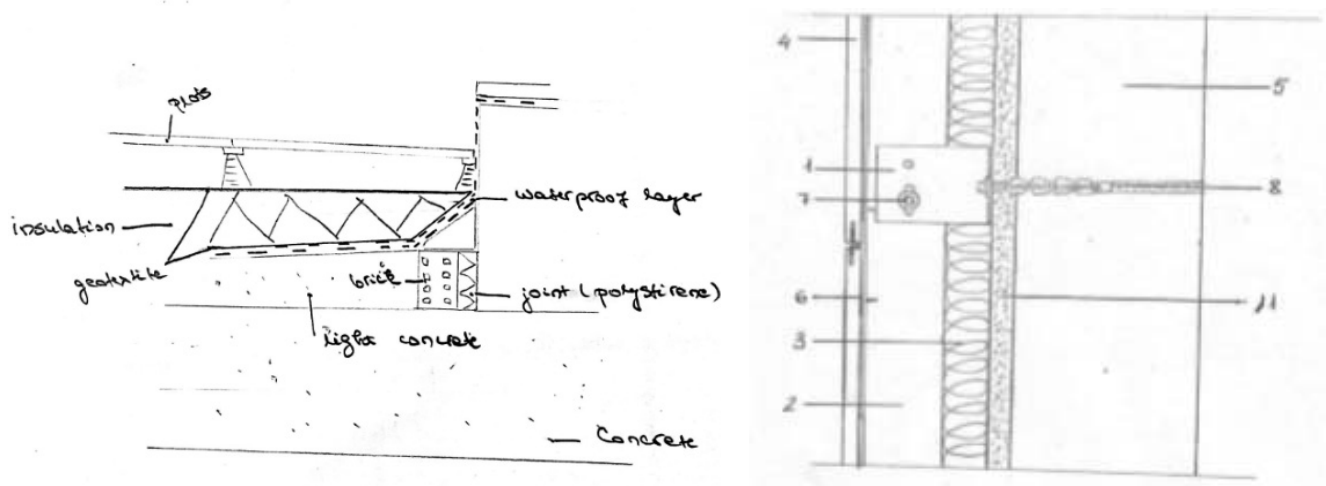

Figure 8. Hand-drawn details of the different construction typologies chosen by students.

Once the constructive details were completed, students continued working in groups to elaborate the descriptive posters (Fig. 9) that included real images of the constructive typologies, the hand-drawn details (Fig. 8), and a brief explanation of the construction process of the chosen typology. The development and assembly of posters was extended until the end of the course.
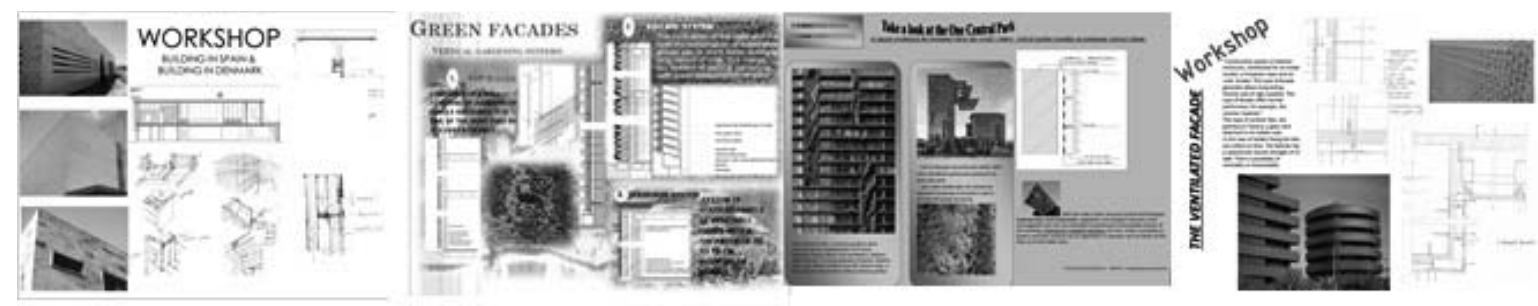

Figure 9. Examples of Student Posters.

\section{CONCLUSIONS}

As a result of this first experience in the development of International Workshops, it has been observed that Spanish students have practise collaborative work. This is the initial step for them to acquire group work skills through the rest of the degree. Furthermore the experience has been particularly satisfactory as a starting activity that will enable students to learn how to be more resolute. Also, it was enriching for the exchange of knowledge between students and teachers of different nationalities.

In addition, this dynamic method allowed students to leave their habitual habitat (classroom of master lesson), letting them to know the possibilities offered by the general library of the Alicante University. Furthermore, the fact of consulting architectural journals allowed them to expand their architectural culture (prestigious architects, award-winning works and emblematic projects).

Likewise, the short lectures of the guest Danish professor have allowed them to know the constructive culture of another country, like Denmark in this case. This fact has encouraged the interaction of Spanish students with Erasmus students from Copenhagen, as an exchange of knowledge and significant differences between countries. Also, since some of the Erasmus students are not architectural technologist but architects or engineers, this experience has facilitated the learning of working under IPD structures. In summary, the interaction between lecturers and students (Both 
Erasmus students and local students) has allowed us to obtain feedback not only on constructive solutions but also in terms of teaching and even social and cultural customs.

\section{FUTURES LINES OF WORK}

The arrangement of furniture in the habitual construction classroom is prepared for traditional master classes. This fact does not favour group work, cooperation and collaboration, marking the differences and hierarchies between lecturer-student. Although Phase 2 of the workshop was developed at the general library of the University of Alicante (in a more relaxed atmosphere with large tables to work in group), the short lecturers of Phase 1 were developed in the usual spaces for teaching.

Furthermore, some of students were still reluctant to speak in English, showing fear of making mistakes about content or language. As a consequence -as future work aimed to integrate shy and insecure student- it is proposed the use of ICTs for the next workshop.

\section{ACKNOWLEDGEMENTS}

This work has been funded by the Institute of Education Sciences of the University of Alicante and the Office of the Vice President for Studies Planning and Training Actions within the Project Networks of research in High Education teaching 2015-2016.

\section{REFERENCES}

[1] G. Castilla Cebrian; M.G.Romana; B. López-Terradas Aparicio, "Concursando en el aula: La gamificación mediante quiz-show como herramienta de dinamización docente". Proceedings of $X$ Jornadas Internacionales de Innovación Universitaria. Educar para transformar. Universidad Europea, Madrid, 11-12 July, pp. 1527-1535, 2013.

[2] M.R. Ariza; M.P. Ferra, "Cómo motivar a aprender en la universidad: Una estrategia fundamental contra el fracaso académico en los nuevos modelos educativos". Revista Iberoamericana de Educación 51, pp. 87-105, 2009.

[3] M.R. Sánchez, "Metodologías docentes en el eees: De la clase magistral al portafolio". Tendencias Pedagógicas, pp. 83-102, 2015.

[4] A.A. Olalla, "Aprendizaje combinado como propuesta en la convergencia europea para la enseñanza de las ciencias naturales". E-learning papers 2007. Retrieved from http://www. elearningeuropa.info/files/media/media12175.pdf

[5] M.D. Andújar-Montoya; E. García González; V. Gilart Iglesias; D. Marcos Jorquera; M.A. Guerrero Lázaro, "Propuesta de uso de last planner como sistema para la enseñanza de gestión del proceso constructivo en el grado en arquitectura técnica en la universidad de Alicante". Proceedings of XIII Jornadas de Redes de Investigación en Docencia Universitaria: Nuevas estrategias organizativas y metodológicas en la formación universitaria para responder a la necesidad de adaptación y cambio. ISBN 978-84-606-8636-1, pp. 2203-2211, 2015.

[6] M.A. López Peral; E. García González; M.D. Andújar-Montoya; A. García-Quismondo Cartes; R. Sánchez Valcárcel; "Gamificación como estrategia para la enseñanza de sistemas estructurales y constructivos", Proceedings of XIV Jornadas de Redes de Investigación en Docencia Universitaria: Investigación, innovación y enseñanza universitaria: enfoques pluridisciplinares, ISBN 978-84-608-7976-3, pp. 2253-2264, 2016.

[7] M.D. Andújar-Montoya; E. García González; M.A. López Peral; A. García-Quismondo Cartes; R. Sánchez Valcárcel; R. Pérez-delHoyo; E. Barba Casanovas, "Aplicación de estrategias de gamificación en la enseñanza de sistemas constructivos", Investigación e Innovación Educativa en Docencia Universitaria. Retos, Propuestas y Acciones. Alicante: Universidad de Alicante, Vicerrectorado de Calidad e Innovación Educativa, Instituto de Ciencias de la Educación. ISBN 978-84-617-5129-7, pp.1724-1738, 2016. 
[8] E. García González; M.D. Andújar-Montoya; M.A. López Peral; A. García-Quismondo Cartes; R. Sánchez Valcárcel; A. Jiménez Delgado; E. Barba Casanovas; R. Pérez-del Hoyo, "Aplicación de estrategias de gamificación en la enseñanza de sistemas constructivos", Investigación e Innovación Educativa en Docencia Universitaria. Retos, Propuestas y Acciones. Alicante: Universidad de Alicante, Vicerrectorado de Calidad e Innovación Educativa, Instituto de Ciencias de la Educación, pp.2844-2858, 2016. 